\title{
Russian weapons labs become the top priority for Western funding
}

\begin{abstract}
Washington. The shock waves that have passed through the international scientific community following the suicide of two prominent Russian science administrators within the space of a few weeks have highlighted the extent to which Western efforts to support science in the former Soviet Union are now focused almost entirely on the activities of the country's nuclear weapons research complex.
\end{abstract}

Up to 15,000 scientists and engineers are receiving direct cash payments from international sources to reduce the chances of their selling nuclear secrets to criminals or foreign governments. The economic situation in the weapons research laboratories has worsened significantly in the past year, with salaries from Minatom, the agency that runs the complex, being delayed by up to four months.

The sense of crisis was heightened by the suicide last month of Vladimir Nechai, director of the Chelyabinsk-70 weapons research laboratory (see Nature 384, 10; 1996), and by the murders and suicide by the director of a computer science institute last week (see below).

But US scientists in regular contact with the Russian weapons laboratories dismiss talk of an impending collapse. The main weapons laboratories at Arzamas-16, 350 $\mathrm{km}$ southeast of Moscow, and at Chelyabinsk-70, just east of the Urals, continue to function with staff at around 80 per cent of their 1990 levels. Civilian laboratories, in contrast, have lost at least half their people.

The International Science and Technology Centre (ISTC), which was established in Moscow in 1994 to kecp the weapons scientists busy, has already received US $\$ 140$ million from the United States, the European Union, Japan and Sweden for the direct support of Russian scientists with expertise in nuclear weapons and other sensitive military technologies.

In contrast to other efforts by Western governments, the ISTC money is distributed directly to each of the Russian scientists engaged in the work.

The system has bypassed both Minatom

\section{IMAGE UNAVAILABLE FOR COPYRIGHT REASONS}

The suicide of Nechai , here with Evgeniy Avrorin, his director of research, caused widespread shock. and the laboratory directors. But, according to a report released last week by the National Research Council (NRC) in Washington DC, it has been "successful and effective" in meeting its primary goal of redirecting weapons scientists towards nonweapons work, and so diminishing the risk of nuclear proliferation.

The ISTC's dynamism contrasts sharply with the faltering progress of other, more widely publicized efforts to aid civilian science and to stabilize the nuclear weapons complex in the former Soviet Union.

After an infusion of $\$ 100$ million from

\section{Institute boss murders five, kills self}

Moscow. A new tragedy hit Russia's scientific community last week with the suicide of the head of a research institute in Kazan, shortly after he had shot four of his senior colleagues and his wife.

The affair comes on the heels of the recent suicide of Vladimir Nechai, director of the Chelyabinsk-70 weapons research laboratory.

In the latest incident, 64-year-old Karen Zhamogortsyan, who was facing staff efforts to replace him as director of the Kazan branch of the Russian Academy of Sciences' Institute of Informatics Problems, shot dead two deputy directors, a department head and a senior scientific worker. $\mathrm{He}$ then instructed his driver to take him home, picked up his wife and drove her to the city hospital. The driver was sent away after parking the car close to the hospital morgue, and Zhamogortsyan shot his wife before killing himself.

As founder of his institute, Zhamogortsyan was known to be depressed because, as a result of financial difficulties, the staff were about to elect a new director. The four scientists shot in the director's study were said to be the main supporters of this move.
George Soros, the billionaire investor, between 1992 and 1995, assistance for civilian science has almost disappeared. Other technical assistance programmes - including $\$ 1.5$ billion allocated by the US Congress since 1992 for Cooperative Threat Reduction (often known as Nunn-Lugar money, after the US senators who conceived it) have been hamstrung by the requirement that the money be spent with US contractors.

Soros is continuing his interest through a $\$ 5$-million contribution to the Civilian Research and Development Foundation, matched by $\$ 5$ million from the US defence department. But George Brown (Democrat, California), the congressman who initiated the foundation, is bitterly disappointed at the failure of the Clinton administration to support it more generously.

The Department of Energy, which runs the US weapons laboratories, has established a "lab-to-lab" programme in Materials Production Control and Accounting - worth \$15 million in 1995 and $\$ 40$ million this year - to control nuclear materials in the Russian weapons complex.

It also has a $\$ 35$-million Industrial Partnering Program to encourage technology transfer from Russian laboratories to US industry. The energy department can spend some of that money in Russia, but the bulk will go to US laboratories and contractors.

The US laboratories are allowed to spend a small amount of money on research at their own discretion, and they have been spending some of that on collaboration with Arzamas and Chelyabinsk-70. But the sums are not large, totalling around $\$ 1$ million at Los Alamos in New Mexico, for example.

The defence department has also awarded some contract work to Russian scientists. The Washington Post revealed last month that, under one such contract, scientists at Arzamas were paid several hundred thousand dollars by the Defense Special Weapons Agency to compile a detailed (but apparently unclassified) history of the Russian nuclear test programme.

Officials at the US State Department say that the total defence department involvement is "hard to pin down". The Central Intelligence Agency does not support work at the Russian laboratories, according to US government officials.

All of this leaves the ISTC as the principal conduit for US support of science in Russia. According to Glenn Schweitzer, the ISTC's first director and author of a new 
book on its origins*, the centre is now reaching some 15,000 of the 60,000 scientists in Russia who possess valuable knowledge of nuclear, biological and chemical weapons and the missiles that deliver them.

At Chelyabinsk-70, he says, there are 5,000 scientists and engineers, and 1,300 of them are being fully or partially supported by $\$ 8$ million from ISTC. Some $\$ 12$ million has gone to the larger weapons laboratory at Arzamas-16, which has 20,000 technical and non-technical staff.

This intervention has helped to alleviate the latest salary crisis at the weapons laboratories. But according to Schweitzer, the situation there is now just as bad as it was during the previous funding crisis in 1992.

Projects submitted to the ISTC are reviewed on three levels - scientific merit, the level of knowledge of weapons of mass destruction held by the scientists involved, and political acceptability of the proposed research. A proposal to investigate hurricanes by firing missiles into them, for example, was deemed politically unacceptable.

According to Steve Gitomer, a scientist at Los Alamos who arranges the review of USfunded ISTC projects, the quality of proposals varies widely. But he says that some good science is emerging, suitable for publication in refereed journals such as the one he edits - IEEE Transactions on Plasma Science.

The NRC report says that the United States should continue to support the ISTC at least until 2003, as it has already pledged to do. It recommends more attention for proposals from scientists with knowledge of biological and chemical weapons.

No-one knows if this effort will ultimately prevent the leakage of knowledge of special weapons from Russia. "I'm somewhat optimistic, but only because it seems that somehow we haven't had any [proliferation] problems so far," says Inta Brikovskis of the NRC staff. "When I see the conditions [in Russia] I wonder how we've been so lucky."

Harley Balzer, a professor at Georgetown University and senior fellow at the Institute of Peace in Washington, who specializes in Russian science issues, worries about the morality of a policy that helps weapons scientists and not others. Balzer thinks that the risk of proliferation, and the justification for supporting the weapons scientists, is greater now than it was in 1992.

Schweitzer, who now works for the NRC but was in Moscow again this week, agrees that Russia and the world face "a very dicey situation" over the next few years. He hopes that the ISTC can help to bridge the gap until the political and economic situation improves and Russia can assert full control over the materials and expertise in its nuclear weapons complex. The alternative is so bad that few are ready even to contemplate it.

Colin Macilwain

*Moscow DMZ: The Story of the International Effort to Convert Russian Weapons Science to Peaceful Purposes (M. E. Sharpe, \$21.95).

\section{Friends and believers bid farewell to Nobel laureate}

London. Religion and science blended seamlessly last Monday, 25 November, when, in an apparently unique event for a Nobel science prizewinner, tens of thousands of people gathered in the north Pakistan town of Rabwah to honour the physicist Abdus Salam, who died on 21 November.

Salam, who was 70 , had been ill for more than a decade. His body was brought to a mosque in London from his house in Oxford, and flown to Lahore on 23 November. It was then taken by road for burial in Rabwah, near Salam's birthplace. Rabwah is the capital of Pakistan's Ahmadiyya community, a controversial and much-persecuted religious minority of which Salam was a member.

Salam was considered an icon and role model among his fellow Ahmadis, and his grave is expected to become a popular shrine. "When people would visit him, they would kiss his hands," says one prominent community member. "To some, he was like a God."

Salam's passions were divided between theoretical physics, religion, Pakistan and the developing world. Last week, tributes flowed from all four, as well as from the Italian town of Trieste, where Salam was founding director of the International Centre for Theoretical Physics, an institution designed to benefit third world scientists. "This is surely the end of an era," says Luciano Bertocchi, deputy director of the centre.

Salam shared the 1979 Nobel physics prize with Sheldon Glashow and Steven Weinberg for unifying electromagnetism and the weak nuclear force. Tom Kibble, professor in the theoretical physics department at Imperial College, London, places Salam among "the first rank of physicists, if you exclude Einstein and Dirac". Kibble joined this department in 1959, two years after it was established by Salam.

Salam remains the only scientist from a Muslim country to have won a Nobel prize. To him, science and faith were inseparable, and he would frequently urge religious leaders to become knowledgeable about science. In a sermon broadcast by satellite on 22 November, Mirza Tahir Ahmad, the head of the Ahmadiyya movement, recalled a discussion in which the Nobel laureate tried to convince Tahir that the speed of light cannot be exceeded. "I told Salam I found this hard to believe as nothing is impossible for God. But he wouldn't have it and drew lots of circles and complicated equations to try and change my mind."

But Salam also suffered for his beliefs in Pakistan, where he was branded an apostate. Followers of Salam's Ahmadiyya faith were declared 'beyond the pale of Islam' by an international panel of Muslim jurists in 1974. Ahmadis differ from Muslims in believing that the second coming of Christ happened in India nearly a century ago.

Salam felt compelled to resign his post as Pakistan's chief scientific adviser in protest following a wave of anti-Ahmadiyya demonstrations. Later governments have

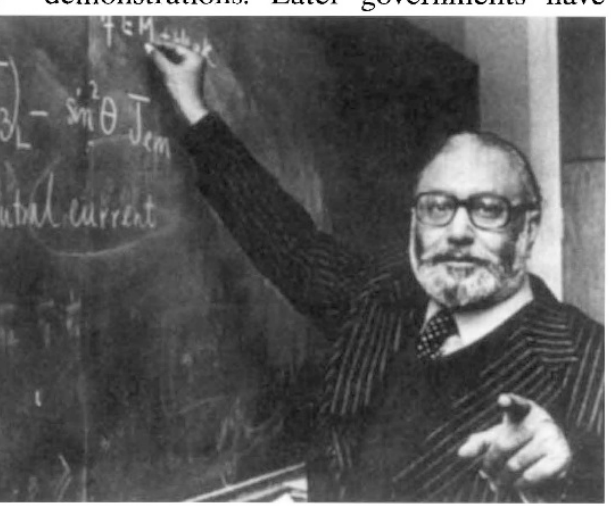

Salam: loyal Pakistani despite falling out of favour.

shied away from mentioning him too often in public to avoid any potential public and political backlash.

In anticipation of potential crowd trouble - which did not develop - security was tight at Salam's funeral. Unmarked police cars accompanied the procession, and plainclothes members of Pakistan's security forces mingled with the crowds.

The Pakistan government has always denied closing the door on Salam, or precipitating his leaving the country in 1974. The former president, General Zia ul Haq, rolled out the red carpet when Salam returned for a visit after winning the Nobel prize. Tributes to Salam following his death came from the current president, Farooq Leghari, and the newly-installed caretaker prime minister, Malik Meraj Khalid.

Salam never publicly criticized the government and insisted on retaining Pakistani citizenship. This continued commitment to Pakistan baffled many, including some of his Pakistani colleagues. "I have never been able to understand why he was so dedicated to this country when he was virtually ostracized here, being an Ahmadi," says Pervez Hoodbhoy, professor of physics at the Quaid-i-Azam University in Islamabad.

"Salam was never embittered and never gave up trying to do what he could for this country," Hoodbhoy adds. Salam's family say they have not yet decided what to do with his archive. But plans are being discussed to put a biography on the Internet.

Ehsan Masood An obituary of Abdus Salam will appear in a future issue. 